Vol. 19 (2010): 302-312.

\title{
Wilting and inoculation of Lactobacillus buchneri on intercropped triticale-fava silage: effects on nutritive, fermentative and aerobic stability characteristics
}

\author{
Adela Martínez-Fernández*, Ana Soldado, Fernando Vicente, Antonio Martínez \\ and Begoña de la Roza-Delgado \\ Department of Animal Nutrition, Grassland and Forages, Regional Institute of Research and \\ Agro-food Development (SERIDA), PO Box 13; E-33300 Villaviciosa (Asturias) Spain \\ *e-mail: admartinez@serida.org
}

\begin{abstract}
This study investigated the effects of wilting and Lactobacillus buchneri inoculation on fermentation end products, DM recovery, nutritive characteristics and aerobic stability in organically grown triticale-fava bean intercrop silages. For this purpose, a bi-crop of triticale $(\times$ Triticosecale Wittm. $)$ and fava bean (Vicia faba L.) was established on an old low-input mixed sward (Lolium perenne-Trifolium repens). The association of triticale and fava bean in winter crops and wilting forages before ensiling improved ensilability characteristics. Wilting for 24 hours before ensiling avoided effluent losses during the fermentation process and reduced ammonia nitrogen production. Inoculation with Lactobacillus buchneri 40788, for a final application rate of $1 \times 10^{5} \mathrm{cfu} \mathrm{g}^{-1}$ of fresh forage ensiled in laboratory silos during 80 days, promoted a higher $\mathrm{CP}$ concentration. Furthermore, it promoted changes in the concentration of fermentation end products, decreasing lactic acid and increasing acetic and propionic acids. The effects of Lactobacillus buchneri on aerobic stability were not confirmed in this study. Wilting depressed, but did not inhibit the activity of Lactobacillus buchneri in the fermentation process.
\end{abstract}

Key-words: Lactobacillus buchneri, wilting, ensilability characteristics, effluent production, nutritive value, organic management 
Vol. 19(2010): 302-312.

\section{Introduction}

In humid temperate areas with oceanic climatic conditions, the most common rotation crops have traditionally been Italian ryegrass-maize (Lolium multiflorum Lam.-Zea mays L.) due to their high productivity. However, the negative effect on soil fertility of this rotation has prompted the introduction of new forage crops that provide an alternative to Italian ryegrass as a winter crop. Some alternatives have been mixtures of grasses with legumes which are able to fix nitrogen in the soil, thereby reducing nitrogen requirements and associated with environmental benefits (Vanotti et al. 1997). Moreover, farmers have become increasingly interested in cereal-legume intercrops for winter-feeding in order to improve the efficiency of production systems. In this respect, Adesogan et al. (2002) have shown pea-wheat bi-crop silages to be both high yielding and environmentally benign forages that promote higher dry matter intake (DMI) and greater nitrogen contents than grass silages. Our research group has tested several legumes in association with winter cereals, including pea-wheat bi-crops, obtaining the best results when combining triticale-fava bean (x Triticosecale Wittm.-Vicia faba L.) in rotation with maize (Pedrol and Martínez 2003, MartínezFernández et al. 2008). In this intercrop, the cereal contributes dry matter and water soluble carbohydrates that improve ensilability characteristics, thus reducing effluent production and minimizing environmental risks. However, this intercrop yields a lower nutritive value than a legume crop alone.

As regards the triticale-fava bean intercrop, the optimal time for mowing is at the initial grain stage for triticale and immature legumes for fava bean (Argamentería et al. 2004). In these phenological stages, high energy and protein values are available as well as lower contents in DM (Arzani et al. 2004, Lloveras-Vilamanya 1987). For this reason, pre-wilting the intercrop before ensiling seems to be necessary. In fact, the higher the DM of the crop, the lower the bacterial activity and the role of fermentation acids in preservation (Wolford 1984).

Some biological additives, such as homofermentative bacteria, improve fermentative activity during the fermentation process, silage nutritive value and animal response in terms of milk and meat production. However, these additives can reduce silage stability during storage and after opening. These effects are due to the lactic acid produced throughout the fermentation process, which is metabolized by some species of yeast and mould upon exposure to oxygen (Combs and Hoffman 2001), and reduced production of antifungal factors (Kung et al. 2003). When air infiltrates the silage during storage, the growth of aerobic microorganisms is stimulated and the process of aerobic deterioration is initiated, leading to dry matter losses of feed, decreasing the feed nutritive value and probably also reducing voluntary feed intake. Yeast acid-tolerant and occasionally acetic acid-tolerant bacteria are the main micro-organisms responsible for consuming nutrients and fermentative residual products, increasing temperature in the silage mass and reducing dry matter and energy (Taylor et al. 2002, Reis et al. 2005).

In contrast, some commercial additives produced with heterofermentative Lactobacillus cultures have demonstrated an ability to inhibit fungal growth (Nishino and Hattori 2005) and have been used to improve the aerobic stability of silages after long-term storage (Kung and Ranjit 2001). Their activity is related to the presence of acetic acid, which inhibits the growth of specific species of yeast responsible for heating upon exposure to oxygen and also decreasing losses during the fermentation process and improving animal production (Kung et al. 2003). Different studies have shown the efficiency of Lactobacillus buchneri 40788, which, when added to fodder that has been harvested, increases acetic fermentation and reduces fungal contamination, thereby improving the aerobic stability of silage by reducing yeast growth (Combs and Hoffman 2001, Kung and Ranjit 2001, Kleinschmit and Kung 2006). The positive impact of L. buchneri appears to be related to acetic acid production. Yeast can be inhibited by the presence of short-chain fatty acids, like acetic acid, which penetrate by passive diffusion into cells and release hydrogen ions, thus decreasing intracellular $\mathrm{pH}$ quickly and resulting in cell death (Ruser and Kleinmans 2005). 
Martinez-Fernández. et al. Wilting and inoculation effects on cereal-legume silage characteristics

The aim of this study was to determine the effects of wilting and Lactobacillus buchneri 40788 inoculation on fermentation end products, DM recovery, nutritive value and aerobic stability in triticale and fava bean intercrop silages grown organically under prevailing weather conditions in wet temperate coastal areas.

\section{Material and methods}

\section{Forages and silages}

This study was conducted on an experimental farm located in the North of Spain (latitude $43.23^{\circ} \mathrm{N}$, longitude $6.07^{\circ} \mathrm{W}$, altitude $65 \mathrm{~m}$ above sea level, Asturias, Spain). The average temperature for the growing period was $10^{\circ} \mathrm{C}$ (ranging between 1 to $16{ }^{\circ} \mathrm{C}$ ) with $78 \%$ relative humidity and $425 \mathrm{~mm}$ of rainfall.

A winter bi-crop of triticale and fava bean ( $\mathrm{x}$ Triticosecale Wittm. and Vicia faba L.) was grown under organic conditions. This bi-crop was established in February 2005, on an old low-input mixed sward (Lolium perenne and Trifolium repens) previously used for grazing and without NPK inorganic fertilizers prior to and during this assay. Sowing was carried out on an experimental single plot area of $360 \mathrm{~m}^{2}$. The viable seeding rate was 159 grains $\mathrm{m}^{-2}$ for triticale and 26 seeds $\mathrm{m}^{-2}$ for fava bean. After 14 weeks of growth, plants were harvested in May 2005 by direct cut method using a mower of cutting bars. The growth stage of forages at the time of harvest was milky grain stage for triticale and pods with grain for fava bean (Fraser et al. 2001). At that time, the triticale-fava bean ratio obtained was 6.3:1. The total yield obtained after harvest was divided in two parts: 1) triticale-fava bean after discarding the weeds from the existing sward (TF), and 2) fava bean alone (F).

Before ensiling, $\mathrm{TF}$ and $\mathrm{F}$ samples were divided in half, with one part being prepared for ensiling in direct cut (D) and the other wilted for 24 hours (W). All fractions to ensiling were cut at $2 \mathrm{~cm}$ using an ORGO precision chopper (Agro ORGA S.A,
Tarragona Spain) and after that ensiled with addition (A) or no addition (NA) of Lactobacillus buchneri NCIMB strain 40788 (Lallemand Animal Nutrition, BP 59, Cedex, France). The additive was prepared diluting $200 \mathrm{~g}$ in 401 of water, and applying one litre of this solution by ton of forage, to obtain a final application rate of $1 \times 10^{5} \mathrm{cfu} \mathrm{g}^{-1}$ of fresh forage.

All material was ensiled at room temperature $\left(20 \pm 5^{\circ} \mathrm{C}\right)$ in laboratory silos made of PVC cylinders provided with bun valves to allow for gas losses, and glass containers to store the evacuated effluent. These laboratory silos have a capacity of $4 \mathrm{dm}^{3}$ and a forage density of $650 \mathrm{~kg} \mathrm{~m}^{-3}$, according to Martínez-Fernández and de la Roza-Delgado (1997). The amount of plant material ensiled was $2.5 \pm 0.25 \mathrm{~kg}$ per silo, and three replicates per treatment. A total of 24 laboratory silages were made. At the end of the fermentative process (80 days), the silos were opened and sampled for analysis. Effluent production was measured throughout the process by weekly weighting.

\section{Analytical methods}

\section{Forages}

Two representative fresh forage samples for total herbage mass were taken and later each one was divided in two parts: $\mathrm{TF}$ and $\mathrm{F}$ (see forages and silages section). All samples (in direct cut and wilted) were analyzed in duplicate for ensilability characteristics, including water soluble carbohydrates (WSC) following Hoffman (1937) and buffer capacity (BC) using the methodology described by Playne and McDonald (1966). The fermentability coefficient (FC) was calculated according to Schmidt et al. (1971), cited by Weissbach (1999). Dry matter in forages (DM) was determined by drying in an air-forced oven at $102{ }^{\circ} \mathrm{C}$ for $24 \mathrm{~h}$. For analytical determinations, a subsample from each treatment was dried at $60^{\circ} \mathrm{C}$ and milled at $0.75 \mathrm{~mm}$. Samples were analyzed for ash and crude protein (CP) according to AOAC (1984), neutral detergent fiber (NDF) (Van Soest et al. 1991) and cellulase 
Vol. 19(2010): 302-312.

digestibility (Riveros and Argamentería 1987) to estimate metabolizable energy (ME) by ARC (1980).

\section{Silages}

After 80 days silos were opened and three subsamples of each experimental silage were collected. The first sub-sample was pressed to obtain juice extract to determine $\mathrm{pH}$, ammonia- $\mathrm{N}$, lactic acid and volatile fatty acids. Ammonia-N was determined by UV-Vis (Ammonium test, Merck, Germany). Lactic acid and volatile fatty acids analyses were performed by HPLC with a Water Alliance 2690 instrument equipped with a Waters 996 Photodiode Array Detector Module (Waters, Milford, Massachusetts) monitoring at $206 \mathrm{~nm}$ and drove by Millenium software. The juice extract were analyzed on a Shodex RSpak KC-811 column (Waters), using a mobile phase with $0.025 \%$ phosphoric acid. Flow rate was $1.0 \mathrm{ml} \mathrm{min}^{-1}$ and column temperature for analyses was kept at $40^{\mathrm{a}} \mathrm{C}$.

The second silage sub-sample was freeze-dried to avoid loss of volatile compounds. After that, samples were milled at $0.75 \mathrm{~mm}$ and analyzed for DM, ash and CP (AOAC 1984), NDF (Van Soest et al. 1991) and cellulase digestibility to estimate metabolizable energy (ME) by ARC (1980).

The third silage sub-sample around $1.5 \pm 0.25 \mathrm{~kg}$ was used for aerobic stability analysis, defined by Moran et al. (1996) as the number of hours the silage mass remained at the baseline temperature before rising $2{ }^{\circ} \mathrm{C}$. Following McEniry et al. (2007), this sub-sample was placed in a polystyrene box $(60 \times 40 \times 15 \mathrm{~cm})$ provided with no hermetic covers and exposed to the air in a room with a controlled temperature of $20 \pm 1{ }^{\circ} \mathrm{C}$. Thermocouples were placed in the middle of the silage in each box and the temperature was automatically recorded each hour for $240 \mathrm{~h}$. Silage $\mathrm{pH}$ was measured directly each day at different positions of the silages using a portable electrode (Inlab 427, Mettler Toledo).

To calculate losses, the material was weighted both in and out of the silos. The proportion of total DM losses was calculated according to the following expression:

$$
\text { Losses }=100-\left(\frac{\text { Silage }(g) \times D M_{\text {silage }}}{\text { Forage }(g) \times D M_{\text {forage }}} \times 100\right)
$$

\section{Statistical Analysis}

Forages data were analyzed to ANOVA by the general linear procedure of SAS (SAS 1999). All silage data were analyzed as a factorial design with type of forage (S), wilting (W) and inoculation (A) as the main factors using again the SAS (1999) general linear models procedure. The model used was:

$\mathrm{Y}_{\mathrm{ijk}}=\mu+\mathrm{S}_{\mathrm{i}}+\mathrm{W}_{\mathrm{j}}+\mathrm{A}_{\mathrm{k}}+\mathrm{SW}_{\mathrm{ij}}+\mathrm{SA}_{\mathrm{ik}}+\mathrm{WA}_{\mathrm{jk}}+$ $\mathrm{SWA}_{\mathrm{ijk}}+\varepsilon_{\mathrm{ijkl}}$

where: $\mathrm{Y}_{\mathrm{ijk} 1}=$ observation, $\mu=$ population mean, $\mathrm{S}_{\mathrm{i}}=$ forage effect ( $\mathrm{i}=1$ to 2 ), $\mathrm{W}_{\mathrm{j}}=$ wilting effect ( $\mathrm{j}$ $=1$ to 2$), \mathrm{A}_{\mathrm{k}}=$ additive effect ( $\mathrm{k}=1$ to 2$), \mathrm{SW}_{\mathrm{ij}}=$ interaction between forage and wilting effects, $\mathrm{SA}_{\mathrm{ik}}$ $=$ interaction between forage and additive effects, $\mathrm{WA}_{\mathrm{jk}}=$ interaction between wilting and additive effects, $\mathrm{SWA}_{\mathrm{ijk}}=$ interaction between forage, wilting and additive effects and $\varepsilon_{\mathrm{ijkl}}=$ residual error. Significant differences were accepted if $p \leq 0.05$.

Aerobic stability was evaluated using an ANOVA with repeated measures testing for statistical significance of $\mathrm{pH}$ and temperature data, collected over 10 days and considering the type of forage, treatment by wilting and additive as fixed effects. The statistical analyses were performed using the SAS (1999) statistical package.

\section{Results}

The ensilability characteristics, chemical composition and estimated ME of fresh forages before ensiling are shown in Table 1. DM was below 200 $\mathrm{g} \mathrm{kg}^{-1}$ in fresh crops and was increased by wilting to about $320 \mathrm{~g} \mathrm{~kg}^{-1}$. The bi-crop (TF) had higher DM (upper than 20\%) and lower CP (around 50\%) proportions than fava bean in direct cut and wilted forages, respectively $(\mathrm{p}<0.001)$. After wilting, significant differences were observed with respect to chemical composition in both forages, with losses in $\mathrm{CP}$ and NDF $(p<0.01)$. 
Martinez-Fernández. et al. Wilting and inoculation effects on cereal-legume silage characteristics

Table 1: Ensilability characteristics, chemical composition and energy content of forages before ensiling.

\begin{tabular}{|c|c|c|c|c|c|c|c|c|}
\hline & \multicolumn{2}{|c|}{ Triticale-Fava bean } & \multicolumn{2}{|c|}{ Fava bean } & \multicolumn{4}{|c|}{ Significance } \\
\hline & Direct & Wilting & Direct & Wilting & s.e.m & $\mathrm{S}$ & W & $\mathrm{S} \times \mathrm{W}$ \\
\hline \multicolumn{9}{|l|}{ Ensilability characteristics } \\
\hline Dry matter $\left(\mathrm{g} \mathrm{kg}^{-1}\right)$ & 206 & 361 & 183 & 280 & 22.4 & $* * *$ & $* * *$ & $* * *$ \\
\hline WSC ( $\left.\mathrm{g} \mathrm{kg}^{-1} \mathrm{DM}\right)$ & 201 & 251 & 94 & 142 & 2.3 & $* * *$ & $* * *$ & NS \\
\hline $\mathrm{BC}\left(\right.$ meq $\left.\mathrm{NaOH} \mathrm{kg}{ }^{-1} \mathrm{DM}\right)$ & 218 & 127 & 319 & 221 & 40.0 & $* * *$ & $* * *$ & NS \\
\hline $\mathrm{FC}$ & 28 & 52 & 21 & 33 & 1.9 & $* * *$ & $* * *$ & $* * *$ \\
\hline \multicolumn{9}{|c|}{ Chemical composition and estimated energy } \\
\hline Crude Protein $\left(\mathrm{g} \mathrm{kg}^{-1} \mathrm{DM}\right)$ & 117 & 111 & 173 & 166 & 0.6 & $* * *$ & $* *$ & NS \\
\hline $\mathrm{NDF}\left(\mathrm{g} \mathrm{kg}^{-1} \mathrm{DM}\right)$ & 550 & 534 & 519 & 491 & 2.1 & $* * *$ & $* *$ & NS \\
\hline $\mathrm{ME}\left(\mathrm{MJ} \mathrm{kg}^{-1} \mathrm{DM}\right)$ & 9.5 & 9.5 & 9.3 & 8.9 & 0.03 & $* * *$ & $*$ & $*$ \\
\hline
\end{tabular}

Significant levels: *, ** and $* * *$ at $p$-values $<0.05,0.01,0.001$, respectively. NS: $p \geq 0.05$. s.e.m.: standard error mean; W: Wilting effect; S: Forage effect; WSC: Water soluble carbohydrates; BC: Buffer capacity; FC: Fermentability coefficient; NDF: Neutral detergent fibre; ME: Metabolizable energy.

Fermentability coefficient was higher in $\mathrm{TF}$ than $\mathrm{F}$ for direct cut and wilting respectively $(p<0.001)$, as a consequence of the higher proportion of water soluble carbohydrates (WSC) and lower buffer capacity (BC) of the former. Furthermore, wilting for 24 hours improved the ensilability conditions in $\mathrm{TF}$ and $\mathrm{F}$, increasing WSC and markedly reducing $\mathrm{BC}$. The interaction between the effect of forage and wilting was also significant $(p<0.001)$.

Table 2 shows the chemical and fermentative characteristics on direct cut and wilted silages inoculated with or without Lactobacillus buchneri at ensiling.

The average DM losses were around $20 \%$ for $\mathrm{TF}$ and F. In direct cut forages DM losses were higher in F than TF, it is inversely related with forage DM content. These losses decrease in wilted forages. As regards the additive effect, losses were higher in both TF and F silages with additive compared to those without inoculation $(p<0.001)$.

The total effluent production in direct cut without additive was higher in $\mathrm{F}$ than TF forages $(p<$ 0.05 ), in concordance with their lower DM content (Table 2). In fact, twenty-four hours of wilting was enough to avoid effluent production during the fermentation period.
Wilting did not affect silage $\mathrm{pH}$, although significant differences were observed in terms of the forage effect $(p<0.01)$. The $\mathrm{pH}$ was higher in $\mathrm{F}$ silages. Wilting time did not affect the chemical composition of silages, except for DM content $(p<$ $0.001)$. The differences due to forage effect showed higher values of ash and $\mathrm{CP}$ and a lower proportion of DM and NDF in F than TF silages, respectively $(p<0.001)$, when comparing the direct cut and wilting effect. ME was not affected by the considered effects ( $\mathrm{S}$ and $\mathrm{W}$ ).

Attending fermentative characteristics, wilting promoted a substantial decrease in the proportion of $\mathrm{NH}_{3}-\mathrm{N}(p<0.001)$ without any effect on $\mathrm{CP}$ content, being ammonia synthesis lower in $\mathrm{F}$ than TF silages $(\mathrm{S} \times \mathrm{W}, p<0.05)$. TF had a lower proportion of lactic and propionic acids and a higher proportion of acetic acid than $\mathrm{F}$, the lactic/acetic acid ratio being lower in TF despite their better FC.

Addition of Lactobacillus buchneri at ensiling increased $\mathrm{pH}(p<0.001)$. The inoculation also increased concentrations of ashes $(p<0.001), \mathrm{CP}$ $(p<0.01)$ and NDF $(p<0.01)$, while decreasing metabolizable energy $(p<0.05)$.

As regards fermentative characteristics, the concentration of lactic acid was lower in silages 
Vol. 19(2010): 302-312.

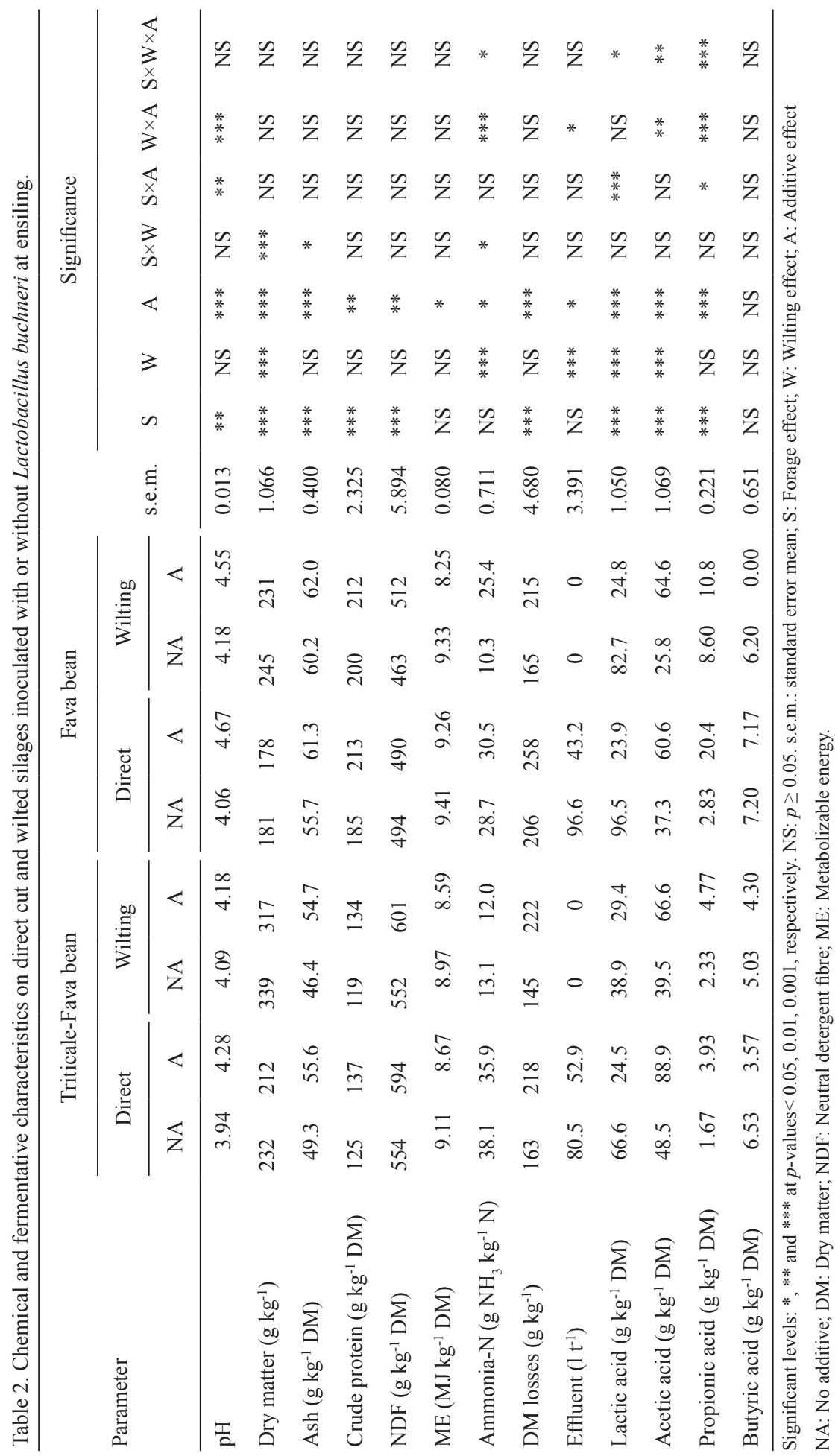




\section{AGRICULTURAL AND FOOD SCIENCE}

Martínez-Fernández. et al. Wilting and inoculation effects on cereal-legume silage characteristics

treated with L. buchneri $(p<0.001)$. In contrast, silages inoculated resulted in a marked increased in the concentration of acetic $(p<0.001)$ and propionic $(p<0.001)$ acids. The additive only increased $\mathrm{NH}_{3}-\mathrm{N}$ synthesis in $\mathrm{F}$, numerically but not statistically $(\mathrm{S} \times \mathrm{A}, p>0.05)$.

Additive treatment increased $\mathrm{pH}$ in both forages (A, $p<0.001)$ while the effect was more clear in $\mathrm{F}(\mathrm{S} \times \mathrm{A}, p<0.01)$, $\mathrm{pH}$ was lower in $\mathrm{TF}$ than in $\mathrm{F}$ $(p<0.01)$. Moreover, the additive showed a strong influence on lactic $(p<0.001)$ and propionic $(p<$ 0.05 ) acids levels in $\mathrm{F}$.

Wilting appeared to inhibit the effects of $L$. buchneri on fermentation parameters because propionic acid (7.77 vs $12.2 \mathrm{~g} \mathrm{~kg}^{-1} \mathrm{DM}$ ) and $\mathrm{NH}_{3}-\mathrm{N}$ (18.7 vs $33.4 \mathrm{~g} \mathrm{NH}_{3} \mathrm{~kg}^{-1} \mathrm{~N}$ ) were $40 \%$ less of those produced in direct cut inoculated silages $(\mathrm{W} \times \mathrm{A}$, $p<0.001)$. Besides acetic acid (65.6 vs $74.7 \mathrm{~g} \mathrm{~kg}^{-}$ $\left.{ }^{1} \mathrm{DM}\right)$ decreased around 20\% $(\mathrm{W} \times \mathrm{A}, p<0.01)$ without differences concerning lactic acid production (27.1 vs $\left.24.2 \mathrm{~g} \mathrm{~kg}^{-1} \mathrm{DM}\right)$.
Chemical parameters of silages were unaffected by interaction among forage, additive and wilting effects, whereas all fermentative characteristics except butyric acid concentration, were affected by this triple interaction. In this sense, in TF forages, with higher ensilability than $\mathrm{F}$, the additive action was less effective reducing lactic acid $(\mathrm{S} \times \mathrm{W} \times \mathrm{A}, p$ $<0.05)$ and increasing acetic $(\mathrm{S} \times \mathrm{W} \times \mathrm{A}, p<0.01)$ and propionic $(\mathrm{S} \times \mathrm{W} \times \mathrm{A}, p<0.001)$ acids. In fava bean $(\mathrm{F})$, with lower ensilability than TF, the additive effects were better than TF, especially in direct cut silages. In the other hand, the additive increases the ammonium concentration in silages with high proteolysis such as wilted fava bean silages $(\mathrm{S} \times \mathrm{W}$ $\times \mathrm{A}, p<0.05)$.

Regardless aerobic stability, all the silages involved in this study remained stable at least 10 days after opening. No heating above room temperature $\left(20 \pm 1^{\circ} \mathrm{C}\right)$ was observed during exposure to air (Table 3). Nevertheless, it should be stressed that according to the statistical analysis of repeated

Table 3. Changes in temperature during air exposure of silages depending on effects: forage, wilting and additive.

\begin{tabular}{|c|c|c|c|c|c|c|}
\hline \multirow{3}{*}{ Day } & \multicolumn{3}{|c|}{ Triticale-Fava bean } & \multicolumn{3}{|c|}{ Fava bean } \\
\hline & Direct & \multicolumn{2}{|c|}{ Wilting } & \multicolumn{2}{|c|}{ Direct } & Wilting \\
\hline & NA & NA & A & NA & A & NA \\
\hline 1 & $18.04 \pm 0.2318 .48 \pm 0.21$ & $18.88 \pm 0.23$ & $18.84 \pm 0.50$ & $19.36 \pm 0.24$ & $19.12 \pm 0.36$ & $19.38 \pm 0.32 \quad 18.58 \pm 0.29$ \\
\hline 2 & $17.10 \pm 0.2016 .84 \pm 0.19$ & $17.56 \pm 0.18$ & $17.36 \pm 0.40$ & $16.98 \pm 0.43$ & $17.80 \pm 0.25$ & $17.82 \pm 0.27 \quad 18.12 \pm 0.16$ \\
\hline 3 & $18.42 \pm 0.1118 .98 \pm 0.04$ & $18.36 \pm 0.05$ & $17.94 \pm 0.44$ & $18.34 \pm 0.09$ & $18.42 \pm 0.13$ & $18.02 \pm 0.25 \quad 18.70 \pm 0.24$ \\
\hline 4 & $17.84 \pm 0.1917 .80 \pm 0.18$ & $18.12 \pm 0.11$ & $17.78 \pm 0.13$ & $17.96 \pm 0.30$ & $17.88 \pm 0.13$ & $18.48 \pm 0.20 \quad 17.96 \pm 0.24$ \\
\hline 5 & $17.68 \pm 0.1917 .82 \pm 0.17$ & $18.20 \pm 0.16$ & $17.92 \pm 0.47$ & $18.22 \pm 0.08$ & $18.00 \pm 0.20$ & $17.94 \pm 0.44 \quad 17.96 \pm 0.33$ \\
\hline 6 & $17.62 \pm 0.1317 .86 \pm 0.21$ & $18.10 \pm 0.23$ & $18.18 \pm 0.36$ & $18.14 \pm 0.33$ & $17.82 \pm 0.08$ & $17.90 \pm 0.19 \quad 18.04 \pm 0.11$ \\
\hline 7 & $18.70 \pm 0.2418 .10 \pm 0.21$ & $18.34 \pm 0.09$ & $19.08 \pm 0.41$ & $18.28 \pm 0.13$ & $18.24 \pm 0.27$ & $18.98 \pm 0.24 \quad 18.86 \pm 0.15$ \\
\hline 8 & $18.70 \pm 0.3218 .16 \pm 0.24$ & $19.20 \pm 0.22$ & $18.78 \pm 0.34$ & $18.44 \pm 0.27$ & $19.24 \pm 0.11$ & $19.06 \pm 0.09 \quad 18.78 \pm 0.27$ \\
\hline 9 & $19.16 \pm 0.1818 .34 \pm 0.10$ & $18.90 \pm 0.35$ & $19.06 \pm 0.28$ & $18.14 \pm 0.21$ & $17.90 \pm 0.23$ & $18.22 \pm 0.33 \quad 18.20 \pm 0.46$ \\
\hline 10 & $19.74 \pm 0.1919 .60 \pm 0.24$ & $19.48 \pm 0.22$ & $19.58 \pm 0.29$ & $19.36 \pm 0.09$ & $18.70 \pm 0.39$ & $18.80 \pm 0.46 \quad 18.70 \pm 0.42$ \\
\hline
\end{tabular}

NA: No Additive; A: Additive. 
Vol. 19(2010): 302-312.
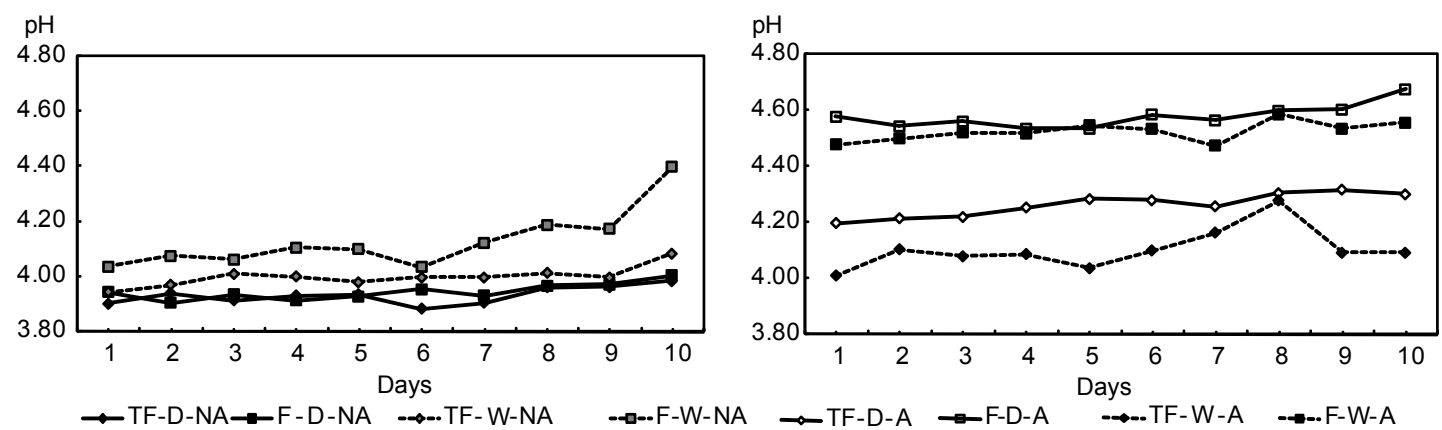

Figure 1. Changes in $\mathrm{pH}$ during aerobic deterioration of triticale-fava bean (TF) and fava bean (F) silages, ensiled directly (D) or wilted (W) and pre-treated with (A) or without (NA) Lactobacillus buchneri.

measures in time, no effects were found with respect to the additive. Marginal differences in final temperature were observed when comparing wilting and direct cut silages after exposure to air.

Figure 1 shows the evolution of $\mathrm{pH}$ over time. $\mathrm{pH}$ was significantly affected by the type of forage (4.12 vs 4.41 for TF and F, respectively; $p<0001$ ) and inoculation (4.41 vs. 4.07 for silage with and without additive, respectively; $p<0001)$. Furthermore, the forage-additive interaction $(p<0.001)$ with the lowest $\mathrm{pH}$ values corresponded to TF forage without additive $(\mathrm{pH}=3.98)$ and the highest to $\mathrm{F}$ silages with additive $(\mathrm{pH}=4.66)$. The $\mathrm{W} \times \mathrm{A}$ interaction $(p<0.001)$ shows that wilting depresses the L. buchneri effect related to $\mathrm{pH}$ evolution after silages aerobic exposure.

\section{Discussion}

The current study provides evidence that adding $L$. buchneri to direct-cut forages of triticale-fava bean and fava bean alone at ensiling increases DM losses. However, this effect decreases in wilted forages, probably because the higher dry matter content in wilted forages decreases the overall activity of $L$. buchneri and therefore less acetic acid is produced. This finding may be explained by the fact that the addition of L. buchneri could have inhibited the activity of yeasts that were probably accelerated by wilting (Nishino and Touno 2005, Oude Elfernick et al. 2001).

The DM content in wilted silages was clearly lower after ensiling than before it. Similar effects were found by Nishino and Touno (2005) on wilted grass silages, and it was explained by gas losses during fermentation process. Interaction in DM content could be explained due to the fact that the proportional increase in DM in F was higher than in TF. When F was wilted before ensiling, the ash content decreased due to leaf loss, while this effect was the opposite in TF. The results of this study showed that wilting forage for 24 hours prior to ensiling reduced lactic and acetic fermentation regardless of the type of forage.

Nishino and Touno (2005) indicated that DM loss was significantly increased when L. buchneri was inoculated into direct-cut materials, in our study this effect was numerically but not statistically significance.

As expected, inoculation with L. buchneri at ensiling altered the fermentation parameters by causing an accumulation of acetic and propionic acids via the metabolism of heterofermentative Lactobacillus culture. These strains transform water soluble carbohydrates into lactic acid at an early stage of fermentation. This lactic acid is further transformed into acetic and propionic acids, the 


\section{AGRICULTURAL AND FOOD SCIENCE}

Martínez-Fernández. et al. Wilting and inoculation effects on cereal-legume silage characteristics

combined action of which has antifungal properties. However, the result of this metabolic process is an increase in final $\mathrm{pH}$. In this experiment, the $\mathrm{pH}$ of silages inoculated with L. buchneri was significantly higher than that of silages which were not inoculated. Moreover, the synthesis of acetic and propionic acids rose during the fermentation process with decreasing lactic acid content. Similar results have been reported with cereal silage by Kung and Ranjit (2001) using different rate of inoculants; alfalfa silage by Kung et al. (2003) after 56 days of ensiling in laboratory silages; whole plant corn silage (Kleinschmit and Kung 2006) or different crop silages (Ruser and Kleinmans 2005). Nishino and Touno (2005) have also reported that in direct-cut grass silages $\mathrm{pH}$ was lower than 4.0 and inoculants treated grass silages had $\mathrm{pH}$ values around 4.5. In contrast, Wróbel (2008) also added commercial inoculants containing homo and heterofermentative lactic acid bacteria to grass forages but found no increases in the $\mathrm{pH}$ values of the resulting silage.

When forages were inoculated at ensiling with L. buchneri, the final silages contained lower concentrations of lactic acid than untreated forages. Conversely, a marked increase in the concentrations of acetic and propionic acid were observed. In a previous study, Combs and Hoffman (2001) reported that silages inoculated with an effective dose (4 to $6 \times 10^{5} \mathrm{cfu} \mathrm{g}^{-1}$ of fresh material) of $L$. buchneri had higher concentration of acetic acid and lower levels of lactic acid than untreated silages. Similar effects were found by Kung et al. (2003) without differences among doses of inoculants.

The ammonia- $\mathrm{N}$ concentration of fava bean silages were increased by inoculation treatment in agreement with Kung et al. (2003) working with alfalfa silages.

In the current study, all silages had very high acetic acid concentrations, which have contributed to the high aerobic stability of them. Although the amount of acetic acid obtained as a result of the $\mathrm{W}$ $\times$ A interaction $\left(65.6 \mathrm{~g} \mathrm{~kg}^{-1} \mathrm{DM}\right)$ did not reach the values obtained in direct cut silages with additive (74.7 $\left.\mathrm{g} \mathrm{kg}^{-1} \mathrm{DM}\right)$, it did remain significantly higher than in direct cut silages without additive $(42.9 \mathrm{~g}$ $\mathrm{kg}^{-1} \mathrm{DM}$ ). Combs and Hoffman (2001) related the beneficial impact of L. buchneri to the production of acetic acid. In fact, aerobic stability could be improved because acetic acid inhibits growth of specific species of yeast that are responsible for heating upon exposure to air. Similar results have also been reported by Taylor et al. (2002) and with those obtained by Nishino and Touno (2005) with Italian ryegrass and Festilolium.

Critics of using heterolactic acid bacteria as silage inoculants suggest that high concentrations of acetic acid in silages have had depressing effects on dry matter intake (DMI) for lactating cows, but at this time it is not clear whether enough acetic acid will be produced in silages treated with L. buchneri to affect feed intake (Combs and Hoffman 2001). Recently, Wróbel (2008) reported that the additive treatment using bacterial inoculants containing homo and heterofermentative lactic acid bacteria, in pre-wilted grass silages (about $450 \mathrm{~g} \mathrm{~kg}^{-1} \mathrm{DM}$ ), and with very low concentrations of acetic acid (ranged between 10.1-14.5 $\mathrm{g} \mathrm{kg}^{-1} \mathrm{DM}$ ), did not affect silage intake and daily live weight gain of heifers.

Inoculation with L. buchneri in forages to make laboratory silages did not affect aerobic stability after 10 days of air exposure. The chosen temperature for the experiment $\left(20 \pm 1^{\circ} \mathrm{C}\right)$ may possibly be too low. In fact, during this study period, no heating above room temperature was observed in the silages. These results are in agreement with those obtained by Taylor et al. (2002), who reported that the temperature of barley silages from laboratory silos did not rise after exposure to air for seven days, and by Combs and Hoffman (2001), who explained that L. buchneri is unlikely to improve silage quality in situations where silage has a history of being aerobically stable at feed out. Our location was probably optimum to maintain silage under stable conditions after exposure to air.

\section{Conclusions}

The results of this study show that the association of triticale with fava bean for ensiling improves ensilability characteristics when compared with 
Vol. 19(2010): 302-312.

fava bean alone. In fact, wilting forage for twentyfour hours before ensiling also increases the fermentability coefficient. Furthermore, this wilting period is sufficient to avoid effluent losses during the fermentation process and to reduce ammonia nitrogen production without changes in $\mathrm{CP}$ content.

Lactobacillus buchneri promotes changes in the amount of fermentation end products, leading to acetate and propionate from lactic acid via the metabolism of heterofermentative biological cultures.

Wilting appeared to depress, but not inhibit the effects of Lactobacillus buchneri on the fermentation parameters. The inhibitory effects of Lactobacillus buchneri on aerobic stability were not confirmed in this study.

Acknowledgements. The authors wish to thank the field and laboratory staff of the Animal Nutrition Grassland and Forages Department at the Regional Institute for Research and Agro-food Development (SERIDA) for their assistance.This study was financially supported by INIA project number RTA2006-00082

\section{References}

Adesogan, A.T., Salawu, M.B. \& Deaville, E.R. 2002. The effect on voluntary feed intake, in vivo digestibility and nitrogen balance in sheep of feeding grass silage or peawheat intercrops differing in pea to wheat ratio and maturity. Animal Feed Science and Technology 96: 161-173.

AOAC. 1984. Official Methods of Analysis Ed: Association of Official Agricultural Chemist. $14^{\text {th }}$ ed. S. Williams (ed). Association of Official Analytical Chemistry, Arlington, Virginia, USA. $1141 \mathrm{p}$.

ARC. 1980. The nutrient requirements of ruminant livestock. Commonwealth Agric. Bureaux. England. 351 p.

Argamentería, A., Roza, B. de la, Martínez-Fernández, A. \& Vicente, F. 2004. Yield of intercropped of triticale and fava bean according to their developing state. Preliminary results. In: Lüscher, A., Jeangros, B., Kessler, W. Huguenim O., Lobsiger M., Millar, N \& Suter, D. (eds). Land Use Systems in Grassland Dominated Regions. Proceedings of 20th General Meeting of the European Grassland Federation in June in Luzern, Switzerland. Zurich. Swiss Grassland Society. p. 101.

Arzani, H., Zohdi, M., Fish, E., Zahedi Amiri, G.H., Nikkhah, A. \& Wester, D. 2004. Phenological effects on forage quality of five grass species. Rangeland Ecology \& Man- agement. 57(6): 624-629.

Combs, D.K. \&. Hoffman, P.C. 2001. Lactobacillus buchneri for silage aerobic stability. In: 5th Arlington Dairy day Proceedings. Dairy Science Department. University of Wisconsin, Madison, USA. p. 28-30.

Fraser, M.D., Fychan, R. \& Jones, R. 2001. The effect of harvest date and inoculation on the yield, fermentation characteristics and feeding value of forage pea and field bean silages. Grass Forage Science 56: 218-230.

Hoffman, W S. 1937. A rapid photoelectric method for the determination of glucose in blood and urine. Journal of Biological Chemistry 120: 51-55.

Kleinschmit, D.H. \& Kung L. 2006. The effects of Lactobacillus buchneri 40788 and Pediococcus pentosaceus R1094 on the fermentation of corn silage. Journal of Dairy Science 89: 3999-4004.

Kung, L. \& Ranjit, N.K. 2001. The effect of Lactobacillus buchneri and other additives on the fermentation and aerobic stability of barley silage. Journal of Dairy Science 84: 1149-1155.

Kung, L., Taylor, C.C., Lynch, M.P. \& Neylon, J. M. 2003. The effect of treating alfalfa with Lactobacillus buchneri 40788 on silage fermentation, aerobic stability, and nutritive value for lactating dairy cows. Journal of Dairy Science 86: 336-343.

Lloveras-Vilamanya, J. 1987. Forage production and quality of several crop rotation and pastures in northwestern Spain. Grass Forage Science 42: 241-247.

McEniry, J., O'Kiely, P., Clipson, N.J.W., Forristal, P.D. \& Doyle, E.M. 2007. Manipulating the ensilage of wilted, unchopped grass through the use of additive treatments. Irish Journal of Agricultural and Food Research 46: 77-91.

Martínez-Fernández, A., Vicente Mainar, F., Roza Delgado, B., \& Argamentería Gutiérrez, A. 2008. Ensilado de haboncillos en monocultivo o asociado a triticale. Pastos. XXXVIII (1), 75-90. (In Spanish).

Martínez-Fernández, A. \& de la Roza, B. 1997. Poder contaminante de los efluentes de ensilados de hierba y raigrás italiano según materia seca del forraje inicial y aditivo utilizado. In: Proceedings of XXXII Reunión Científica de la Sociedad Española para el Estudio de los Pastos in May in Sevilla, Spain. Sevilla: Junta de Andalucía, p. 199-204. (In Spanish).

Moran, J. P., Weinberg, Z. G., Ashbell, G., Hen, Y. \& Owen, T. R. 1996. A comparison of two methods for the evaluation of the aerobic stability of whole crop wheat silage. In: Proceedings of. XI International Silage Conference. Aberystwyth, UK, p. 162-163.

Nishino, N. \& Hattori, H. 2005. The use of Lactobacillus buchneri. Inoculation to decrease ethanol and 2,3-butanediol production in whole crop rice silage. In: Park, R.S. \& Stronge, M.D. (eds). Silage Production and Utilisation. Proceedings of the 14th International Silage Conference, Belfast, Northern Ireland. Wageningen Academic Publishers, The Netherlands. p. 261.

Nishino, N. \& Touno, E. 2005. Ensiling characteristics and aerobic stability of direct-cut and wilted grass silages inoculated with Lactobacillus casei or Lactobacillus buchneri. Journal of the Science of Food and Agriculture 85: 1882-1888.

Oude Elfernick, S.J.W.H., Krooneman. J., Gottschal, J.C., Spolestra, S.F., Faber, F. \&, Driehuis, F. 2001. Anaero- 


\section{AGRICULTURAL AND FOOD SCIENCE}

\section{Martínez-Fernández. et al. Wilting and inoculation effects on cereal-legume silage characteristics}

bic conversion of lactic acid to acetic acid and 1,2-propanediol by Lactobacillus buchneri. Applied and Environmental Microbiology 67:125-132.

Pedrol, N. \& Martínez, A.2003. Asociaciones cereal-leguminosa en rotaciones forrajeras ecológicas de zonas húmedas. In: Robles-Cruz, A.B. et al. (eds). Pastos, desarrollo y conservación. Ptoccedings of XLIII Reunión Científica de la Sociedad Española para el Estudio de los Pastos. Junta de Andalucía, Spain, p. 131136. (In Spanish).

Playne, M. J. \& McDonald, P. 1966. The buffering constituents of herbage and of silage. Journal of the Science of Food and Agriculture 17: 264-268.

Reis, R.A., Almeida, E.O., Siqueira, G.R., Bernardes, T.F., Janusckiewiez, E.R. \& Roth, M.T.P. 2005. Microbial changes and aerobic stability in high moisture maize silages inoculated with Lactobacillus buchneri. In: Park, R.S. \& Stronge, M.D. (eds). Silage Production and Utilisation. Proceedings of the 14th International Silage Conference, Belfast, Northern Ireland. Wageningen Academic Publishers, The Netherlands. p. 223.

Riveros, E. \& Argamentería, A. 1987. Métodos enzimáticos de la predicción de la digestibilidad in vivo de la materia orgánica de forrajes. I. Forrajes verdes. II. Henos. III Ensilados y pajas. Avances en Producción Animal. 12: 49-75. (In Spanish).

Ruser, B. \& Kleinmans, J. 2005. The effect of acetic acid on the aerobic stability of silages and on intake. In: Park, R.S. \& Stronge, M.D. (eds). Silage Production and Utilisation. Proceedings of the 14th International Silage Conference, Belfast, Northern Ireland. Wageningen Academic Publishers, The Netherlands. p. 231.

SAS. 1999. SAS Institute, SAS/STATTM, 1999. User's Guide. Release 8.2. SAS Institute, Inc. 10 Cary, NC.
Schmidt, L., Weissbach, F., Wemecke, K-D \& Hein, E. 1971. Erarbeitung von Parametern für die Vorhersage und Steuerung des Gärungsverlaufes bei der Grünfutter silierung. Forschungsbericht, Oskar-Kellner- Institut für Tierenährung Rostock. (In German).

Taylor, C.C., Ranjit, N.J., Mills, J.A., Neylon, J.M. \& Kung, L. 2002. The effect of treating whole plant barley with Lactobacillus buchneri 40788 on silage fermentation, aerobic stability, and nutritive value for lactating dairy cows. Journal of Dairy Science 85: 1793-1800.

Vanotti, M.B., Bundy, L.G. and Peterson, A.E. 1997. Nitrogen fertilization and legume-cereal rotation effects on soil productivity and organic matter dynamics in Wisconsin, In: Paul, E.A. et al. (eds). Soil organic matter in template agrosystems. CRC Press, Boca Raton, Florida, USA, p.105-120.

Van Soest, P.J., Robertson, J.B. \& Lewis, B.A. 1991. Methods of dietary fiber, neutral detergent fiber, and nonstarch polysaccharides in relation to animal nutrition. Journal of Dairy Science 74: 3583-3597.

Weissbach, F. 1999. Consequences of grassland de-intensification for ensilability and feeding value of herbage, in: Landbauforschung Völkenrode, (ed.). Contributions of Grassland and Forage Research to the development of Systems of Sustainable Land Use. Institute of Crop and Grassland Science of the Federal Agriculture Research Centre (FAL), Braunschwig, Germany, p. 41-53.

Wolford, M.K. 1984. The silage fermentation, Marcel Dekker, INC, New York, USA. 350 p.

Wróbel, B. 2008. Quality and aerobic stability of bigbale silage treated with bacterial inoculants containing Lactobacillus buchneri. Grassland Science in Europe 13: 651-653. 